\title{
A Geochemical Appraisal of Some Marble Physiques in Ubo Area and Environs, Southwestern Nigeria
}

\author{
*ODOKUMA-ALONGE, O \\ Department of Geology, Faculty of Physical Sciences, University of Benin, Benin City, Edo State, Nigeria \\ Corresponding Author Email: ovie.odokuma-alonge@uniben.edu, Tel: 08039631428
}

\begin{abstract}
Twenty (20) marble samples from Ubo and environs were analyzed both geochemically and statistically with the aim of determining their industrial applicability. The samples were subjected to AAS analysis. Findings revealed a fairly high - very high values of $\mathrm{CaO}(52.98 \mathrm{wt} \%-82.18 \mathrm{wt} \%)$ and low values of $\mathrm{MgO}(1.64 \mathrm{wt} \%-6.95 \mathrm{wt} \%)$. Other major oxide such as $\mathrm{SiO}_{2}, \mathrm{FeO} / \mathrm{Fe}_{2} \mathrm{O}_{3}, \mathrm{Na}_{2} \mathrm{O}, \mathrm{K}_{2} \mathrm{O}, \mathrm{Al}_{2} \mathrm{O}_{3}$ and $\mathrm{MnO}_{2}$ had values below $2 \mathrm{wt} \%$. The multivariate analysis employed revealed a high correlation between $\mathrm{CaO} / \mathrm{Fe}_{2} \mathrm{O}_{3}, \mathrm{MgO} / \mathrm{Al}_{2} \mathrm{O}_{3}$ and $\mathrm{FeO} / \mathrm{CaO}$ which is an indication of their fairly similar valencies and ionic values. The high lime content is connected to the shallow marine environment during deposition prior to metamorphism. The marbles are classified as the high calcite group and their industrial use range from the production of Portland cement to their use for ceramics.
\end{abstract}

\section{DOI: https://dx.doi.org/10.4314/jasem.v23i6.29}

Copyright: Copyright (C) 2019 Odokuma-Alonge. This is an open access article distributed under the Creative Commons Attribution License (CCL), which permits unrestricted use, distribution, and reproduction in any medium, provided the original work is properly cited.

Dates: Received: 12 August 2018; Revised: 10 May 2019; Accepted 20 June 2019

Keywords: Marble, Chemical-composition, Metamorphism, Correlation,

Despite abundant petrological and structural studies as well as geological mapping performed over several decades in Igarra and environs by (Emofurieta, 1984; Folami and Ojo, 1991; Obasi, 2012; Onimisi et al., 2015; Obasi et al., 2015; Kayode and Enu, 1976), not much research and detailed geological mapping have not been done on the marble Formations in Ubo area. Marble is a major raw material for industries and results from metamorphism of limestone, a carbonate sedimentary rock formed in shallow marine and lake environments which is further subjected to change in temperature $\left(150^{\circ}-650^{\circ} \mathrm{C}\right)$ and pressure $(3 \mathrm{~kb}-15 \mathrm{~kb})$ (Mason, 1966). This study is aimed at classifying the marble in the study area geochemically in a bid to determine its applicability in the industrial sector. Multivariate statistical analysis was also used to determine the elemental relationship between the major oxides and help to reconstruct the paleoenvironmental conditions that probably existed during the deposition of the sediments. The study area is located in Ubo area Akoko-Edo LGA, SW Nigeria and lies between latitude $\mathrm{N}^{\circ} 7^{\circ} 18^{\prime} 10^{\prime \prime}$ to $\mathrm{N} 07^{\circ} 20^{\prime} 8^{\prime \prime}$ and longitude E006 $18^{\prime} 34^{\prime \prime}$ to E006 27'29.4" on Auchi Sheet 266 on a scale of 1:100,000 covering an area extent of $95.58 \mathrm{~km}^{2}$ (Figure 1). The Nigerian Basement Complex forms part of the trans-Saharan Pan African mobile belt of neo-Proterozoic (500-750Ma) age situated between the Archean-Paleo-Proterozoic blocks of the West African Craton to the west, the east Saharan blocks to the east and the Congo Craton to the southeast. The evolution of the Nigerian basement complex took place within, at least four orogenic events viz: Liberian (2800 $\pm 200 \mathrm{Ma})$, Eburnean $(1950 \pm 200 \mathrm{Ma})$, Kibaran $(1100 \pm 200 \mathrm{Ma})$ and the Pan African Orogeny $(600 \pm 150 \mathrm{Ma})$. The Pan-African
Orogeny was the most important, evidenced by the development of the Older Granites (Oyawoye, 1964). Rahaman, (1989) identified six major rock types and they are: (1) Migmatite - gneiss - quartzite complex (2) Slightly migmatized to non-migmatised metasedimentary and meta- igneous rocks which are often referred to as Newer metasediment (Oyawoye, 1970) or the Schist belts. (3) Charnockitic, gabbroic and dioritic rocks. (4) Members of the Older granite suite. (5) Metamorphosed to unmetamorphosed calcalkaline volcanic and hypabyssal rocks (McCurry, 1976; McCurry and Wright, 1971). (6) Unmetamorphosed dolerite dykes, basic dykes and syenite dykes etc. Furthermore, Odeyemi, (1988) divided the rocks in Igarra areas as belonging to the:(i) Migmatites, biotite and biotite- hornblende gneisses. (ii) Low grade metasediments, (schists, calcsilicate gneisses, marbles, polymict metaconglomerates and quartzites) (iii) Syn-late tectonics porphyritic biotite and biotite hornblende granodiorites and adammellites, charnockites and gabbros, unmetamorphosed dolerites, pegmatites, aplites and syenite dykes.

The Ubo body is associated with crystalline rocks of the Precambrian basement complex including migmatites, quartzites, porphyritic granites, the granites, charnockites, calc-gneisses, pegmatites, biotite and biotite hornblende granites (Figure 2). The outcrop was mined by the then Bendel Cement Factory but remnant of the body showed it is white in colour and very coarse grained in texture. It has sharp contact with the charnockites. A pegmatitic dyke of about $30 \mathrm{~cm}$ thick cross-cuts the body. There is a reaction zone between the charnockites and the marble body. 
The orientation of the Ubo marble is within west of NNS-NE-EW trends with dip values of $26^{\circ}-90^{\circ}$.

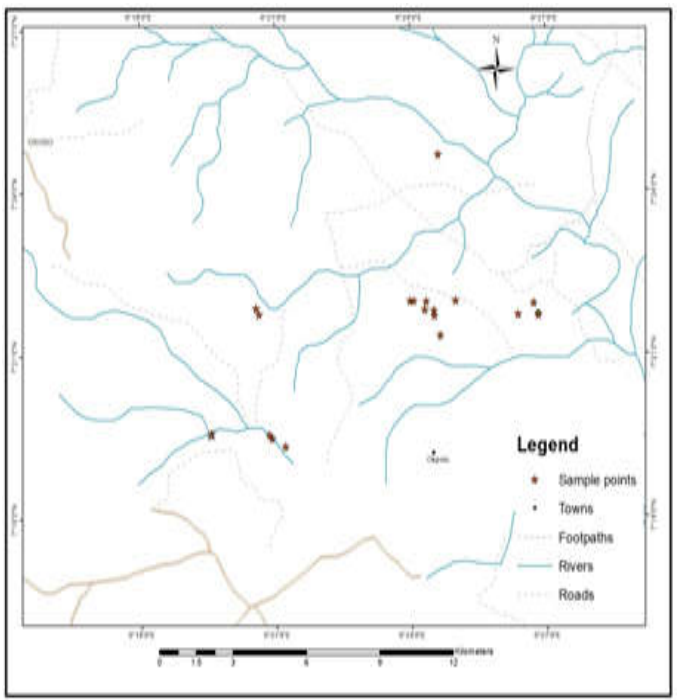

Fig.1: Map of study area showing sample locations

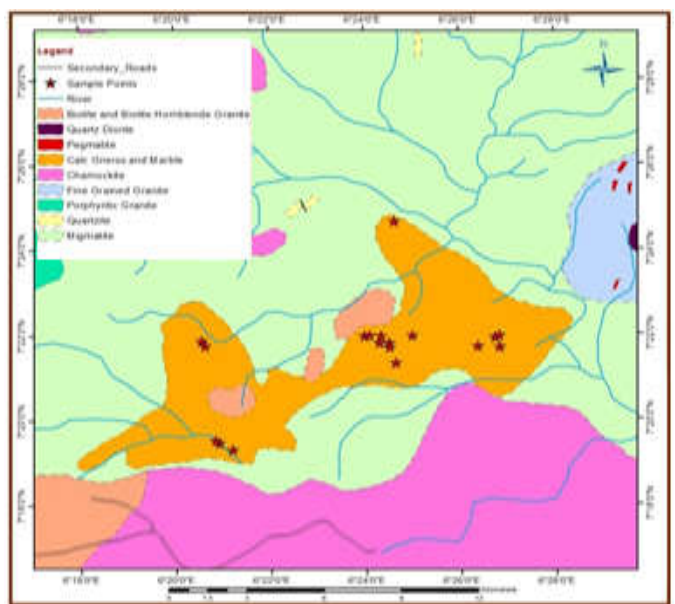

Fig.2: Geologic map of study area (GSN, 2015)

\section{MATERIALS AND METHODS}

Sample Collection: Twenty (20) samples were collected from different locations within the study area using a sledge hammer.

Sample Preparation and Analysis: The samples, well labeled, were pulverized using a disc mill to reduce the size and increase the surface area during digestion. The reagents used were all of analytical grade (Adler, 1971). $1 \mathrm{gm}$ of the sample was weighed into a teflon crucible. $5 \mathrm{ml}$, of concentrated HF was added to the powdered sample. Effervescence occurred and the teflon crucible was placed in the sand-bath which was heated to a temperature of $120^{\circ} \mathrm{C}$ for 30 minutes. $5 \mathrm{ml}$ of concentrated $\mathrm{HClO}_{3}$ was added and placed in the sand-bath for another 10-30 minutes until the substance was molten. The crucible was brought down to cool slightly and $5 \mathrm{ml}$ of concentrated $\mathrm{HCl}$ was finally added. The sample was allowed to cool and made up to $250 \mathrm{ml}$ with de-ionized water and finally poured into well labeled sampled bottles in preparation for further geochemical analysis $(25 \mathrm{ml}$ for dilution factor of 100) (Thompson and Wood, 1981). The alkali metals $\mathrm{K}^{+}$and $\mathrm{Na}^{+}$were analyzed using a flame photometer. The instrument was switched on and allowed to stand for 1 hour to be stabled. It was calibrated with the highest and lowest standard series to obtain a linear range (working range). The standard series of the order $0,2,4,6,8,10 \mathrm{ppm}$ were determined with the resultant values recorded. The Atomic Absorption Spectrophotometer (AAS) was used to determine the other major elements.

\section{RESULTS AND DISCUSSION}

Table 1 shows the major elements of the marble from the area of study. The $\mathrm{Na}_{2} \mathrm{O}$ values range of 0.03 $043 \%, \mathrm{~K}_{2} \mathrm{O}$ from $0.02-0.84 \%, \mathrm{CaO}$ from 52.98$82.18 \%, \mathrm{MgO}$ from $1.11-6.95 \% \mathrm{SiO}_{2}$ from $0.01-$ $0.03 \% \mathrm{MnO}_{2}$ from $0.01-0.04 \% \mathrm{Al}_{2} \mathrm{O}_{3}$ from 0.01 $0.34 \%, \mathrm{Fe}_{2} \mathrm{O}_{3}$ from $0.03-1.31 \%$ and $\mathrm{FeO}$ from 0.05 $1.52 \%$. The mean values for the major oxides range between $0.02 \%-63.82 \%$ for $\mathrm{MnO}_{2}$ and $\mathrm{CaO}$, respectively. All the samples in this study had $\mathrm{MgO}$ values $<6 \%$ except sample 5 which suggests they are low magnesium marble (Brown, 2007). The low $\mathrm{MgO}$ in the area could be mainly due to low dolomite content in the rock which is probably as a result of slight replacement of $\mathrm{Ca}^{2+}$ with $\mathrm{Mg}^{2+}$ and also probably contribution of magnesium rich organic matter in low temperature environments (Pettijohn, 1975).

The low $\mathrm{Al}_{2} \mathrm{O}_{3}(0.01-0.34 \%)$ could be attributed to the absence of aluminosilicates or probably due to the low energy environment of the area at the time of deposition. Alkali content of the rock is known to be $<$ $1 \%$. Clarke (1924) is of the opinion that alkali content decreases in marbles with increase in salinity. The alkali content of Ubo marble could be considered to have formed in a relatively deep shallow environment with very little input from salty brine water in the basin (Onimisi et al., 2015; Olatunji, 1989). The fairly high - high value of $\mathrm{CaO},(58.98-82.18 \%)$ is an indication that the marble in study area are calcitic in composition and the $\mathrm{CaO} / \mathrm{MgO}$ ratio range from 9 - 40. Sample 5 had a $\mathrm{CaO} / \mathrm{MgO}$ of 9.10 owing to the high $\mathrm{MgO}$ content of $6.95 \%$ while sample 9 had a $\mathrm{CaO} / \mathrm{MgO}$ of 40 owing to the very high value of $\mathrm{CaO}(82.18 \%)$ and low value of $\mathrm{MgO}(2.05 \%)$. The high $\mathrm{CaO}$ content in sample 9, 16 and 19 can be attributed to large amount of Ca-rich mineral (calcite) in the environment. The inter-elemental association was determined statistically with the aim of determining the relationships between variables and their relevance to the actual problem being studied. For this study, Pearson's correlation matrix was used to determine a linear relationship between two variables (Webbs and Howarth, 1979). Table 2 shows the correlation matrix for the major oxides in the study. It was observed that there is a very strong positive correlation between $\mathrm{M}_{2} \mathrm{O}$ 
vs $\mathrm{Al}_{2} \mathrm{O}_{3}(+0.838), \mathrm{FeO}$ vs $\mathrm{Fe}_{2} \mathrm{O}_{3}(+0.999), \mathrm{CaO}$ vs $\mathrm{Fe}_{2} \mathrm{O}_{3}(+0.803), \mathrm{FeO}$ vs $\mathrm{CaO},(+0.793)$ and a fairly strong positive correlation between $\mathrm{MgO}$ vs $\mathrm{CaO}$ $(+0.634), \mathrm{SiO}_{2}$ vs $\mathrm{K}_{2} \mathrm{O}(+0.650)$ and $\mathrm{Al}_{2} \mathrm{O}_{3}$ vs $\mathrm{CaO}$ $(+0.479)$. The strong positive correlation between $\mathrm{CaO}$ vs $\mathrm{Fe}_{2} \mathrm{O}_{3}, \mathrm{FeO}$ vs $\mathrm{CaO}$ and $\mathrm{MgO}$ vs $\mathrm{CaO}$ can be attributed to their similar valencies owing to the easy substitution and replacement of $\mathrm{CaO}$ for $\mathrm{Fe}_{2} \mathrm{O}_{3}, \mathrm{FeO}$ and $\mathrm{MgO}$.

Table 1: The chemical composition of the samples in the study area

\begin{tabular}{|c|c|c|c|c|c|c|c|c|c|}
\hline $\mathrm{S} / \mathrm{No}_{0}$ & $\mathrm{Na}_{2} \mathrm{O}$ & $\mathrm{K}_{2} \mathrm{O}$ & $\mathrm{Ca}_{3} \mathrm{O}$ & $\mathrm{MgO}$ & $\mathrm{SiO}_{2}$ & $\mathrm{MnO}_{2}$ & $\mathrm{Al}_{2} \mathrm{O}_{3}$ & $\mathrm{Fe}_{2} \mathrm{O}_{3}$ & $\mathrm{EeO}$ \\
\hline 1. & 0.14 & 0.05 & 67.03 & 2.05 & 0.07 & 0.01 & 0.05 & 0.14 & 0.20 \\
\hline 2. & 0.08 & 0.02 & 58.82 & 3.27 & 0.08 & - & 0.10 & 0.03 & 0.05 \\
\hline 3. & 0.07 & 0.36 & 58.28 & 2.45 & 0.08 & 0.02 & 0.06 & 0.16 & 0.24 \\
\hline 4. & 0.43 & 0.54 & 67.03 & 2.86 & 0.03 & 0.08 & 1.05 & 1.52 & \\
\hline 5. & 0.05 & 0.02 & 63.25 & 6.95 & 0.07 & - & 0.02 & 0.26 & 0.38 \\
\hline 6. & 0.08 & 0.34 & 65.14 & 2.05 & 0.02 & - & 0.01 & 0.74 & 1.07 \\
\hline 7. & 0.08 & 0.02 & 69.83 & 4.09 & 0.02 & - & 0.01 & 0.17 & 0.25 \\
\hline 8. & 0.05 & 0.02 & 63.25 & 2.86 & - & - & 0.03 & 0.21 & 0.32 \\
\hline 9. & 0.24 & 0.07 & 82.18 & 2.05 & - & 0.01 & 0.08 & 0.40 & 0.58 \\
\hline 10. & 0.16 & 0.10 & 65.14 & 1.64 & 0.02 & - & 0.06 & 0.09 & 0.12 \\
\hline 11. & 0.24 & 0.43 & 67.04 & 2.86 & - & - & 0.08 & 1.31 & 1.90 \\
\hline 12. & 0.25 & 0.19 & 58.39 & 1.64 & 0.03 & - & 0.05 & 0.14 & 0.19 \\
\hline 13. & 0.32 & 0.84 & 58.39 & 4.19 & - & 0.02 & 0.34 & 0.41 & 0.62 \\
\hline 14. & 0.30 & 0.10 & 63.8 & 1.64 & 0.01 & 0.03 & 0.02 & 0.25 & 0.37 \\
\hline 15. & 0.24 & 0.10 & 61.36 & 2.86 & 0.04 & 0.01 & 0.10 & 0.12 & 0.16 \\
\hline 16. & 0.08 & 0.02 & 78.4 & 5.32 & 0.02 & 0.01 & 0.17 & 0.31 & 0.45 \\
\hline 17. & 0.08 & 0.05 & 62.44 & 3.68 & 0.02 & 0.03 & 0.12 & 0.08 & 0.12 \\
\hline 18. & 0.11 & 0.02 & 59.82 & 3.27 & 0.04 & 0.04 & 0.10 & 0.06 & 0.09 \\
\hline 19. & 0.22 & 0.08 & 70.29 & 2.86 & 0.02 & 0.02 & 0.14 & 0.25 & 0.36 \\
\hline 20. & 0.08 & 0.02 & 52.98 & 2.05 & 0.01 & 0.01 & 0.11 & 0.07 & 0.10 \\
\hline Mean & 0.15 & 0.09 & 63.82 & 2.91 & 0.03 & 0.02 & 0.11 & 0.16 & 0.23 \\
\hline SD. & 0.09 & 0.11 & 7.42 & 1.11 & 0.03 & 0.01 & 0.04 & 0.09 & 0.13 \\
\hline
\end{tabular}

$S D=$ standard deviation

Table 2: Correlation matrix for major elements of study area

\begin{tabular}{lccccccccc}
\hline & $\mathrm{Na}_{2} \mathrm{O}$ & $\mathrm{K}_{2} \mathrm{O}$ & $\mathrm{CaO}$ & $\mathrm{MgO}_{2}$ & $\mathrm{SiO}_{2}$ & $\mathrm{MnO}_{2}$ & $\mathrm{Al}_{2} \mathrm{O}_{3}$ & $\mathrm{Fe}_{2} \mathrm{O}_{3}$ & $\mathrm{FeO}$ \\
\hline $\mathrm{Na}_{2} \mathrm{O}$ & 1.000 & & & & & & & & \\
$\mathrm{~K}_{2} \mathrm{O}$ & 0.057 & 1.000 & & & & & & & \\
$\mathrm{CaO}$ & 0.126 & -0.260 & 1.000 & & & & & & \\
$\mathrm{MgO}$ & -0.436 & -0.282 & 0.634 & 1.000 & & & & & \\
$\mathrm{SiO}_{2}$ & -0.268 & 0.630 & -0.128 & -0.190 & 1.000 & & & & \\
$\mathrm{MnO}_{2}$ & 0.079 & 0.000 & -0.210 & -0.042 & -0.131 & 1.000 & & & \\
$\mathrm{Al}_{2} \mathrm{O}_{3}$ & -0.377 & -0.398 & 0.479 & 0.838 & -0.371 & -0.193 & 1.000 & & \\
$\mathrm{Fe}_{2} \mathrm{O}_{3}$ & 0.359 & 0.083 & 0.803 & 0.302 & -0.206 & -0.235 & 0.188 & 1.000 & \\
$\mathrm{FeO}^{2} \mathrm{O}$ & 0.337 & 0.100 & 0.793 & 0.297 & -0.203 & -0.203 & -0.171 & 0.999 & 1000 \\
\hline
\end{tabular}

The $\mathrm{CaO} / \mathrm{MgO}$ ratio range from 9.10 in sample 5 to 40.08 in sample 9 is a reflection of abundance of calcite in the area. The $\mathrm{MgO}$ content in the sample is < $6.95 \%$ hence can be considered to be classified as pure marble (Cherneva et al., 2009; Bassey, 2011) due to the low $\mathrm{MgO}$ content. The low silica, alumina and potash values indicate the low presence of quartz and feldspars in the area (Oyinloye, 2012). Where the $\mathrm{CaO} / \mathrm{MgO}$ content $>12$, the marbles are considered to be high calcite marble, where they occur between 412 , they are considered to be high magnesian marble and where $<4$ are considered to be dolomitic in composition (Cherneva et al., 2015). From this study all the samples indicate they belong to high calcite varieties except two samples (5 and 13) which gave values of 9.10 and 11.89 , hence are high magnesian in composition. The marble in the study area are very useful for the production of cement when mixed with clays. $\mathrm{CaO}$ content ranges between $52.98-82.91 \mathrm{wt} \%$ far above the basic requirement of $\mathrm{CaO}(\geq 35 \%)$ for cement production. Chips can also be crushed and used as terrazzo chips, concrete aggregate, ballast, road stone; massive or cut to shape and used for travertine for walls, floors slaps for shops and furniture, paving, kerbs and building stones; Cut, their crystals are used for nicol prisms in petrological microscopes; Milled for their optical properties and pigments such as paris white precipitated calcium carbonate (PCC), lake pigments white wash, paints, paper fill, paper coating plastic, rubber, linoleum, painting links; Precipitated as aerosols for mine dusting, printing and rolls, precipitated as abrasives for toothpaste, tooth powders, polishing powders; precipitated as fillers for cosmetics especially face powders, adhesives, pharmaceuticals including tableted goods and antibiotics. The naturally fine-grained varieties are used as sources of mineral 
nutrient for preparata in bread and animal feeds stuffs. They could also be used as neutralizing in agriculture, pharmacies, water treatment, acid trade effluents and fermentation industries. When subjected to thermal treatments burnt lime $(\mathrm{CaO})$ is hydrated $\mathrm{Ca}(\mathrm{OH})_{2}$ and used for the manufacture of bleaching powder, ammonia, calcium carbide $\left(\mathrm{CaC}_{2}\right)$, fertilizer, wood alcohol, soap, glycerin, glue, glass pottery and sugar; In tanneries are used in sewage, wool scouring, textiles and dyes; as budding lime in mortars, cements, pozzuolanas etc. as insecticides and fungicides; In lime - silica reaction products. When lime is reacted with silica can be used for flux in smelting operations, especially steel forming blast furnace slag, ceramics and glass (Robertson, 1960).

Conclusion: The marble in the study area are high calcite in classification with $\mathrm{CaO} / \mathrm{MgO}>12$. Statistically, the high positive correlation of $\mathrm{CaO}$ vs $\mathrm{Fe}_{2} \mathrm{O}_{3}, \mathrm{MgO}$ vs $\mathrm{Al}_{2} \mathrm{O}_{3}, \mathrm{FeO}$ vs $\mathrm{CaO}$ and fairly high values of $\mathrm{MgO}$ vs $\mathrm{CaO}, \mathrm{SiO}_{2}$ vs $\mathrm{K}_{2} \mathrm{O}$ is attributable to the similar valencies of $\mathrm{Fe}, \mathrm{Ca}, \mathrm{Mg}$ and quite close ionic values of $\mathrm{Al}, \mathrm{Si}$, and $\mathrm{K}$, respectively.

Acknowledgement: A lot of thanks go to the University of Benin, Research Publishing Committee (URPC) for making funds available for the completion of this research work

\section{REFERENCES}

Adler, I (1971): Methods in geochemistry and geophysics, 8. Elemental analysis in geochemistry, Elsevier Publ. Co. Amsterdam, London, New York, 303- 326

Bassey, EE (2011). Compositional appraisal and quality implications of a metacarbonate deposit occurring in parts of southeastern Nigeria. RMZMat. Geo-enviro., 58 (4), 405-420.

Brown, T (2007). Setting the standard in the natural stone industry. Marble Institute of America, 278 p.

Cherneva, Z; Geogieva, M; Stoilkova, T; Petrova, A; Herimova, S (2009). Geochemistry of metacarbonate rocks from the Arda tectonic unit in the central Rholdope, Bulgaria. Abstracts of National Conference, Geosciences.

Clarke, FN (1924). The data of geochemistry ( $2^{\text {nd }}$ Eds.) Washington Government Printing Office, 782p.
Emofurieta, WO (1984). The geochemistry of Igbeti Granite Complex, Oyo State, Nigeria. Unpubl. $\mathrm{Ph} . \mathrm{D}$ Thesis, University of Ile-Ife, Nigeria.

Folami, SL; Ojo, JS (1991). Gravity and magnetic investigations over marble deposits in the Igarra area, Bendel State. Jour. Min. Geol. Nigeria, 27 (1), 49-54.

Geology Survey Nigeria, (GSN) (2015). Publ. 111-125 Geological Survey of Nigeria, (GSN), Auchi Sheet 266, scale 1: 100,000.

Kayode, A. A; Enu, E. I (1976). An association of parawollastonite and wollastonite from the UboOkpella-Oguda- Ubo River area, Bendel State, Nigeria. Unpubl. M. Sc. University of Ife, Ile-Ife, Nigeria.

Mason, B. (1966). Principles of Geochemistry, $3^{\text {rd }}$ Edition, John Wiley and Sons, New York

McCurry, P (1976). The geology of the Precambrian to Lower Paleozoic rocks of northern Nigeria. A review in Kogbe, C. A. Ed. Geology of Ile-Ife, 15- 39.

McCurry, P; Wright, JB (1971). On place and time in orogenic granite plutonism. Geol. Soc. Amer. Bull., 82, 1713-1476.

Obasi, RA (2012). Geochemical and appraisal of the economic potential of calc-gneiss and marble from Igarra, Edo State, SW, Nigeria. $A R P N J$. Sci. Technol. (10), 1018-1021.

Obasi, RA; Anike, OL; Ogungbiyi, PI (2015). Trace and rare earth elements geochemistry of marble from Ikpeshi, its provenance and paleo-redox conditions. Inter. J. Sci. Technol. 4, (1), 14-25

Odeyemi, IB (1988). Lithostratigraphy and structural relationships of the Upper Precambrian metasediments in Igarra area, SW, Nigeria. In: Oluyide et al., (eds.) Precambrian Geology of Nigeria.

Olatunji, JA (1989). Chemical characterization of Isale-Osin marble Kwara State. Geoscience Consultancy Report for Ministry of Commerce and Industry, Ilorin, Kwara State

Onimisi, M; Ariffin, KS; Hussin, HB; Baharun, NBT (2015). Petrographic and geochemical characteristic of metacarbonate in Northcentral 
Nigeria: Potential application in Industries. $J$. Geo. Environ. Earth Sci. Intern. 3 (3):1-10.

Oyawoye, MO (1964). The geology of the Nigerian basement complex of Nigeria. J. Min. Geol. Met. Soc. 1.

Oyawoye, MO (1976). The basement geology of Nigeria; In African Geology, Ibadan 1970 Eds. Dessauvagie and Whiteman, Geology Department, University of Ibadan, Nigeria.

Oyinloye, AO (2012). Geology and geotectonic setting of the Basement Complex rocks in southwestern Nigeria: Implications on provenance and evolution. Earth. Environ. Sci. (5), 98-117.

Pettijohn, FJ (1975). Sedimentary Rocks (3rd Edition) Warper and Row, New York, 628p.
Rahaman, M. A (1989). Review of basement geology of southwestern Nigeria. Geology of Nigeria, Edited by C. A. Kogbe, $2^{\text {nd }}$ Edition, 39-63.

Robertson, JA (1960). Mineral Deposits Studies. Ontorio Ministry of Natural Resources

Thompson, M; Wood, SJ (1981). Atomic absorption methods in applied geochemistry.

Applied Geochemistry Research Group, Rept. of Geology, Imperial College, London 272-273.

Webbs, JS; Howarth, RJ (1979). The significance of fluid inclusions in metamorphic rocks. D. G. Fraser (ed.) Thermodynamics in geology, Reided Dorthrecht, 27-203. 